특집논문-11-16-2-03

$$
\begin{gathered}
\text { 지상파 스테레오스코픽 3DTV 방송을 위한 이종 부호화기 기반 } \\
\text { 합동 비트율 제어 연구 } \\
\text { 장 용 준ㄹ), 김 문 철ㅎ }
\end{gathered}
$$

\title{
Dual Codec Based Joint Bit Rate Control Scheme for Terrestrial Stereoscopic 3DTV Broadcast
}

\author{
Yongjun Chang ${ }^{\text {a) }}$ and Munchurl Kim ${ }^{\text {a) }}$
}

요 약

최근 3차원 영상 콘텐츠와 디스플레이의 증가에 따라 지상파 방송사들은 스테레오스코픽 3차원 텔레비전(3DTV) 방송을 위한 준비를 시작하고 있다. 하지만 현재 지상파 방송사들이 비디오 전송을 위하여 사용하고 있는 ATSC 방송규격의 약 $18 \mathrm{Mbps}$ 대역폭 제한 내에서 는 고화질의 스테레오스코픽 영상을 전송하는 데 한계가 있다. 따라서 보다 고화질의 $3 \mathrm{D}$ 영상 방송 서비스를 제공하는 동시에, 기존 $2 \mathrm{DTV}$ 시청자를 위한 호환성을 유지하기 위하여 좌영상은 현재 지상파 방송에서 채택하고 있는 MPEG-2 기반, 그리고 우영상은 보다 압축 효율이 높은 H.264/AVC 기반의 비디오 압축 및 전송 시스템이 고려되고 있다. 본 연구에서는 이러한 지상파 3DTV 방송 조건 하 에서 이종 부호화기로부터 산출되는 비트스트림의 양을 대역폭 제한에 맞게 조절하는 합동 비트율 제어 방법을 제안한다. 제안하는 합동 비트율 제어 방법은 H.264/AVC의 비트율 제어 방법인 이차 율-양자화 모델(quadratic rate-quantization model)을 MPEG-2 부호화 과정 내에 구현하여 압축된 두 비디오 비트스트림의 합이 대역폭 조건을 충족시키면서 화질왜곡을 최소화하는 양자화계수를 계산하도록 설계 되었다. 또한 시청자의 시각적 피로도가 양안 영상의 화질 차이와 관계가 있다는 가정 하에 좌영상과 우영상의 화질의 차이를 일정하게 유지되도록 하는 제약식을 최적화 문제에 추가하여 양자화계수를 계산하였다. 실험결과 제안한 지상파 스테레오스코픽 3DTV를 위한 합 동 비트율 제어 알고리듬은 목표 비트율을 맞추는 동시에, MPEG-2 및 H.264/AVC의 기존 비트율 제어 알고리듬 방법에 비하여 좌/우 영상의 평균 화질 합을 약 $2.02 \%$ 향상시켰고, 화질 절대차의 평균은 약 $77.6 \%$, 화질차의 분산은 약 $74.38 \%$ 감소시키는 성능을 보였다.

\begin{abstract}
Following the proliferation of three-dimensional video contents and displays, many terrestrial broadcasting companies have been preparing for stereoscopic 3DTV service. In terrestrial stereoscopic broadcast, it is a difficult task to code and transmit two video sequences while sustaining as high quality as 2DTV broadcast due to the limited bandwidth defined by the existing digital TV standards such as ATSC. Thus, a terrestrial 3DTV broadcasting with a heterogeneous video codec system, where the left image and right images are based on MPEG-2 and H.264/AVC, respectively, is considered in order to achieve both high quality broadcasting service and compatibility for the existing 2DTV viewers. Without significant change in the current terrestrial broadcasting systems, we propose a joint rate control scheme for stereoscopic 3DTV service based on the heterogeneous dual codec systems. The proposed joint rate control scheme applies to the MPEG-2 encoder a quadratic rate-quantization model which is adopted in the H.264/AVC. Then the controller is designed for the sum of the left and right bitstreams to meet the bandwidth requirement of broadcasting standards while the sum of image distortions is minimized by adjusting quantization parameter obtained from the proposed optimization scheme. Besides, we consider a condition on maintaining quality difference between the left and right images around a desired level in the optimization in order to mitigate negative effects on human visual system. Experimental results demonstrate that the proposed bit rate control scheme outperforms the rate control method where each video coding standard uses its own bit rate control algorithm independently in terms of the increase in PSNR by $2.02 \%$, the decrease in the average absolute quality difference by $77.6 \%$ and the reduction in the variance of the quality difference by $74.38 \%$.
\end{abstract}

Keyword : stereoscopic 3DTV broadcast, joint bit rate control, quadratic rate-quantization model, linear distortionquantization model, heterogeneous dual codec system 


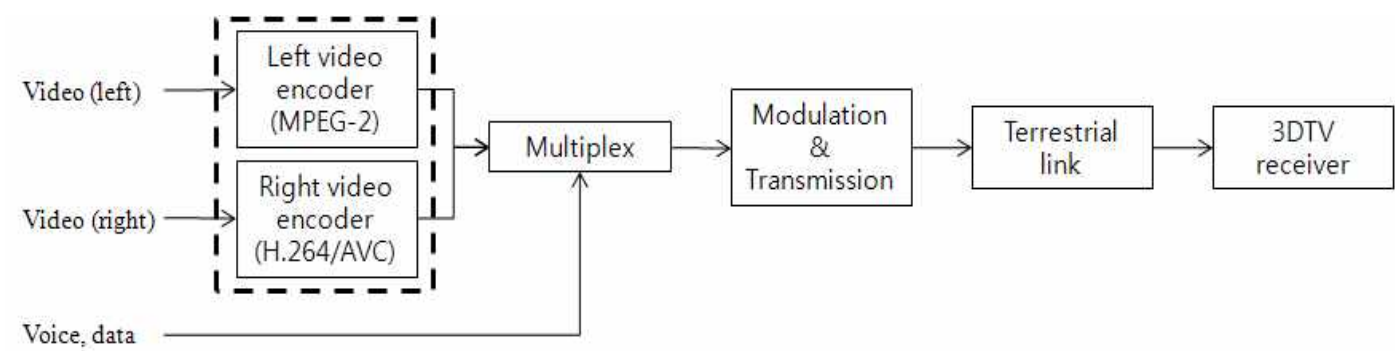

그림 1. 본 연구에서 가정한 3DTV 지상파 방송 방식

Fig. 1. Tentative terrestrial 3DTV broadcasting system

\section{I. 서 론}

헐리우드 영화 아바타를 계기로 $3 \mathrm{D}$ 비디오 콘텐츠 및 디 스플레이의 수요가 증가함에 따라 현재 지상파 방송사들은 시험방송 등 본격적인 스테레오스코픽 3DTV 지상파 방송 송출 준비를 서두르고 있다. 스테레오스코픽 3DTV 지상파 방송은 현재 사용 중인 ATSC (Advanced Television Systems Committee) 방송 규격을 그대로 유지하는 한, 기존의 비디오 전송 대역폭인 약 $18 \mathrm{Mbps}$ 를 유지하면서 좌영상과 우영상을 동시에 송출해야 한다 ${ }^{[1]}$. 따라서 현재 MPEG-2 기반의 2D 고해상도 TV (High Definition TV) 수준의 화질 을 맞추는 데 한계가 있다. 제한된 대역폭 내에 화질을 항상 하기 위해서 MPEG-2보다 더 압축 효율이 높은 H.264/ $\mathrm{AVC}$ 와 같은 비디오 표준 방식을 좌/우 영상에 모두 사용하 는 방법을 고려할 수 있지만, 기존 2DTV 시청자들을 위한 호환성 측면에서 양안 영상 중 적어도 하나의 영상은 MPEG-2 방식으로 부호화 하는 방식이 유지되어야 한다. 따라서 호환성을 유지하는 동시에 대역폭 제한 조건 하에 서 화질을 최적화 하기 위한 3DTV 지상파 방송 방식으로 서, 그림 1과 같이 좌영상은 기존 지상파 방송 비디오 압축 표준인 MPEG-2를 이용하고, 우영상은 MPEG-2에 비해 압 축효율이 큰 H.264/AVC로 압축하여 두 비트스트림을 다

a) 한국과학기술원

Korea Advanced Institute of Science and Technology

\# 교신저자 : 김문철 (mkim@ee.kaist.ac.kr)

※ 본 연구는 지식경제부 및 정보통신산업진흥원의 대학 IT연구센터 지원사업의 연구결과로 수행되었습니다(NIPA-2011-(C1090-1111-0003)). · 접수일(2010년12월21일), 수정일(2011년3월3일),게재확정일(2011년3월16일)
중화해서 송신하는 방법이 고려되고 있다 ${ }^{[2]}$.

이러한 방송 방식에 있어서 서로 다른 이종 부호화기로 부터 산출되는 비트스트림은 서로 다른 신호적 특성을 보 이기 때문에, 두 비트스트림을 동시에 고려하여 비트율 합 이 대역폭 조건 내에서 화질의 합을 최대가 되게 하는 비트 율 제어 방법의 연구가 요구된다. 본 연구에서는 H.264/ $\mathrm{AVC}$ 에서 사용하고 있는 2차 율-양자화 모델(quadratic rate- quantization model) $)^{[3,4]}$ 을 MPEG-2 부호화 과정 내에 구현하여 압축된 두 비디오 비트스트림의 합이 대역폭 조 건을 충족시면서 화질왜곡을 최소화하는 최적화 관점의 합 동 비트율 제어 방법(joint bit rate control scheme)을 고안 하였다.

한편, 인간이 인지하는 스테레오스코픽 3차원 영상의 주 관적 화질은 근사적으로 좌/우 영상의 주관적 화질의 평균 값과 유사하지만 ${ }^{[5]}$, 한 영상의 압축도가 어느 한계를 넘어 서 양안 영상 간의 화질차가 일정 수준 이상이 되면 주관적 화질이 급격히 떨어진다는 연구가 진행되었다 ${ }^{[6]}$. 비록 양안 영상의 화질차와 시청자의 주관적 피로도 간의 관계에 대 한 연구는 아직까지 발견하기 어렵지만, 본 연구에서는 과 거 주관적 화질 연구 ${ }^{5,6]}$ 을 바탕으로 좌/우 영상 간 화질차가 일정 수준을 유지하는 조건에서 좌/우 영상 간의 화질 차이 로 인하여 발생하는 부정적 영향(예를 들면 안구 피로 등) 을 최소화 할 수 있다고 가정하였다. 이러한 전제 하에 본 연구에서 가정하고 있는 이종 부호화기 기반 지상파 스테 레오스코픽 서비스에서 양안 영상 간의 화질차이를 일정하 게 유지시키는 것은, 일정한 목표 비트율을 두 부호화기에 각각 할당하여 비트율을 제어하는 기존 방식으로는 달성하 기 힘든 문제이다. 예를 들어 그림 2에서는 MPEG-2와 


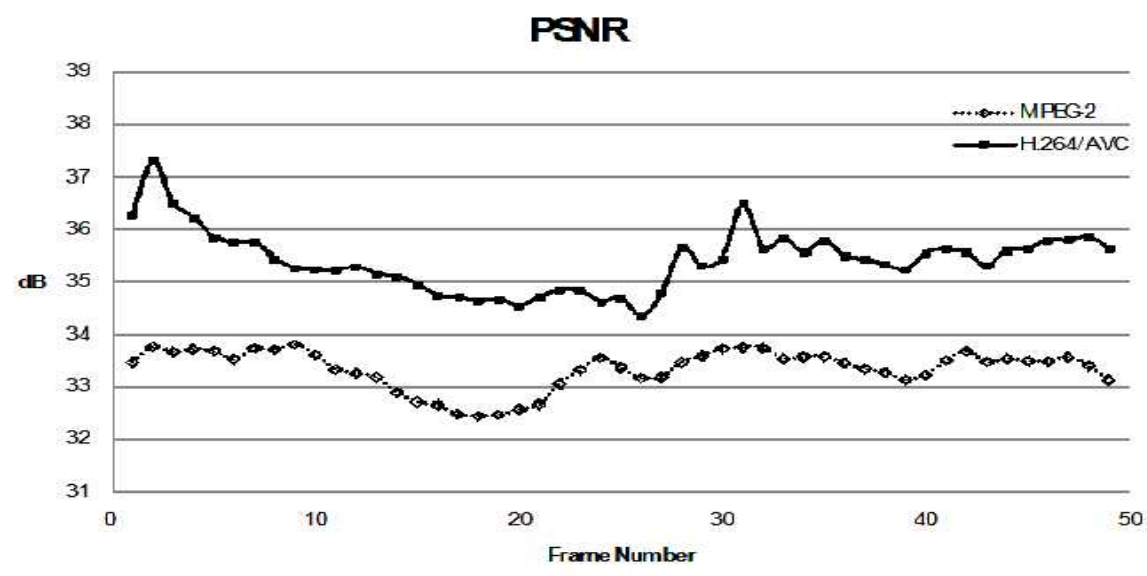

(a) Foreman CIF sequence

PSNR

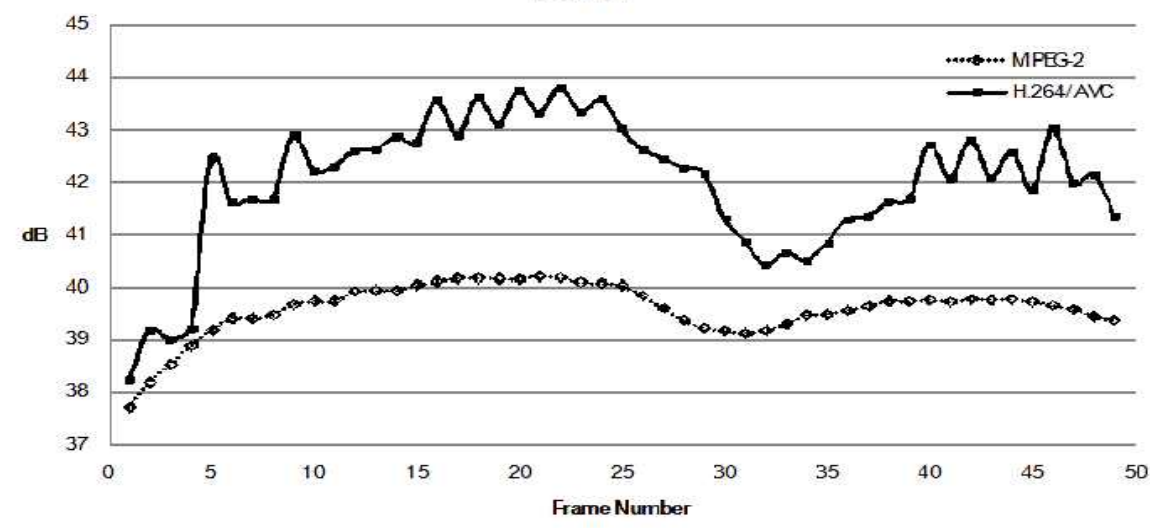

(b) Mother\&Daughter CIF sequence

그림 2. MPEG-2, H.264/AVC로 부호화 된 좌/ 우 영상의 화질차 (목표비트율-MPEG-2: 500kbps, H.264/AVC: 250kbps; IPPP, 50 프레임)

Fig. 2. Quality difference between the left and right videos (Target bitrate-MPEG-2: $500 \mathrm{kbps}$, H.264/AVC: $250 \mathrm{kbps}$; IPPP, 50 frames)

H.264/AVC에 각각 $500 \mathrm{kbps}$ 와 $250 \mathrm{kbps}$ 의 비트율을 할당 하고 각 부호화기에서 채택하고 있는 비트율 제어 알고리 듬을 독립적으로 이용하여 CIF 크기의 Foreman 영상과 Mother \& Daughter 영상을 부호화 했을 때 산출된 P 프레 임들의 화질을 PSNR로 나타내었다. 본 연구의 사전 실험 결과인 그림 2에서 보듯이 Foreman 영상의 경우 1.08 3.56 $\mathrm{dB}$, Mother \& Daughter 영상의 경우 0.33 3.63 dB의 좌/우 영상 화질차를 나타냈으며, 시간에 따른 좌/우 영상간의 화 질차도 일정하지 않고 변화하는 경향을 나타내었다. 같은 영상에 대하여 이렇게 좌/우 영상간의 화질차가 일정하지
않은 이유는 본 연구에서 가정하고 있는 이종 비디오 부호 화 시스템에서 MPEG-2로 부호화된 좌영상 신호와 H.264/AVC로 부호화된 우영상 신호가 서로 상이한 특성 을 갖기 때문이다. H.264/AVC는 율-왜곡 최적화, 가변 블 록 크기 움직임 예측, $1 / 4$ 화소 움직임 예측, 중간값 기반 움직임 예측, 다중 참조프레임, 인트라 예측 모드, $4 \times 4$ 블록 $\mathrm{DCT}$ 기반 정수 변환, 그리고 향상된 엔트로피 코딩 등 MPEG-2에 비하여 부호화 효율을 향상시키기 위한 알고리 듬들이 채택된 표준이다[7]. 그 결과 $250 \mathrm{kbps}$ 의 목표 비트 율을 할당한 H.264/AVC의 화질이 $500 \mathrm{kbps}$ 의 목표 비트율 
을 할당한 MPEG-2보다 더 높은 화질을 보임을 알 수 있다. 즉, 이종 부호화기 기반의 지상파 스테레오스코픽 방송에 서 일정한 비트율을 좌/우 영상에 독립적으로 할당하였을 경우, 영상에 따라, 그리고 부호화기의 특성에 따라 좌/우 영상의 화질차가 일정하게 유지되지 않는다는 사실이 그림 2 와 같이 관찰되며, 이러한 좌/우 영상 화질차가 시각 피로 도에 영향을 미친다는 가정하에 본 연구에서는 이 문제를 대역폭 제한 조건 하의 복호 화질 최적화 문제에 좌/우 영상 의 화질차를 일정하게 유지하는 제약식을 추가함으로써 해 결하고자 시도하였다.

\section{II. 합동 비트율 제어 알고리듬}

\section{1. $2 \mathrm{D}$ 비디오 비트율 제어 알고리듬}

각 비디오 압축 표준들은 압축 효율을 높이기 위하여 서 로 구별되는 많은 기술들을 포함하고 있다. 예를 들어 최근 표준으로 제정된 H.264/AVC의 경우 부호화 과정 내에 율왜곡 최적화, 가변 블록 크기 움직임 예측, $1 / 4$ 화소 움직임 예측, 다중 참조프레임, $4 \times 4$ 블록 $\mathrm{DCT}$ 기반 정수 변환, 그 리고 향상된 엔트로피 코딩 등 다른 표준과 차별되는 특징 을 갖는다 ${ }^{[7]}$. 따라서 서로 다른 압축 과정들을 거쳐 산출된 이종 부호화기 비트율 역시 서로 구별되는 신호적 특성을 갖게 된다. 이러한 산출 비트율을 미리 정해진 목표 비트율 에 최대한 근사시키기 위하여 각 비디오 압축 표준들마다 권장하는 비트율 제어 알고리듬들을 참조 소프트웨어 내에 구현하고 있다. 본 연구에서 고려하는 비디오 압축 표준인 MPEG-2 비트율 제어의 경우 픽쳐 타입과 복잡도에 따라 할당 비트량을 정하고, 목표 비트량 및 버퍼 충만도에 의한 매크로블록 단위의 양자화계수 결정 과정을 거쳐, 공간적 인 복잡도와 왜곡 크기에 따라 양자화계수 값을 조정해주 는 적응적 과정을 거친다 ${ }^{[8]}$. H.264/AVC의 경우 MPEG-4 에서 제안된 2차 율-양자화 모델에 예측 오차를 대표하는 잔차신호의 평균절대차합(Mean Absolute Difference: $\mathrm{MAD}$ ) 추정 등 다른 조건을 추가한 비트율 제어 알고리듬
이 사용되고 있다. 이 알고리듬은 우선 유동트래픽모델 및 선형추적이론에 기반해 GOP (Group Of Pictures) 단위와 프레임 단위의 비트량을 할당하고, 이 목표 비트율을 이용 한 2차 율-양자화 모델을 도입함으로써 비트율 제어를 위한 양자화계수 값을 계산한다. 이때 이전 프레임의 $\mathrm{MAD}$ 정보 로부터 예측된 현재 프레임의 $\mathrm{MAD}$ 값을 이용하게 된다마. H.264/AVC의 비트율 제어 알고리듬에서 사용하고 있는 2 차 율-양자화 모델은 다음과 같다마.

$$
\frac{a}{q}+\frac{b}{q^{2}}=R_{T}
$$

식 (1)에서 $q$ 는 양자화 스텝사이즈 (MPEG-2에서는 mquant, H.264/AVC에서는 Qstep), $R_{T}$ 는 목표 비트율, 그 리고 $a, b$ 는 모델 파라미터를 의미한다. 이 모델 파라미터 $a, b$ 는 예측 오차인 $\mathrm{MAD}$ 를 포함하며, 선형회귀모델을 이 용하여 비디오 콘텐츠에 따라 적응적으로 업데이트 된다. 위 식 (1)에서 구한 양자화계수를 이용하여 H.264/AVC 프 레임 단위 비트율 제어가 실행된다.

\section{2. 최적화 기반 스테레오스코픽 3D 비디오 합동 비트율 제어}

H.264/AVC의 비트율 제어는 2차 율-양자화 모델인 식 (1)을 기반으로 수행되는데 이 식 (1)은 화질 왜곡 $(D)$ 이 양 자화 스텝사이즈 $(q)$ 에 관한 단조 증가 함수로 표현될 경우 다음 식 (2)의 최적화 문제로 표현할 수 있다.

$$
\begin{aligned}
& \min D \\
& \text { s.t. } R \leq R_{T}
\end{aligned}
$$

위 식 (2)에서 프레임 비트율 $R$ 은 2차 율-양자화 모델인 $R=\frac{a}{q}+\frac{b}{q^{2}}$ 이다. 따라서 제안하는 스테레오스코픽 $3 \mathrm{DTV}$ 방송을 위한 비트율 제어 방법은 식 (3)에서와 같이 좌영상, 우영상 각각의 비트율의 합이 목표 비트율을 넘지 않는 조 건 하에서, 목적함수로 주어지는 복호화 된 좌/우 영상들의 왜곡 합을 최소화하는 최적화 문제로 접근할 수 있다. 


$$
\begin{aligned}
& \min D_{1}+D_{2} \\
& \text { s.t. } R_{1}+R_{2} \leq R_{T}
\end{aligned}
$$

위 식 (3)에서 $D_{i}$ 는 $i$ 번째 영상의 왜곡, 즉 MSE (Mean Squared Error), $R_{i}$ 는 $i$ 번째 영상의 비트율을 나타내며, $i=1$ 은 좌영상 부호화기 MPEG-2를, $i=2$ 는 우영상 부호화기 H.264/AVC를 의미한다. 이제 위 최적화 문제 (3)을 비트율 제어 변수인 양자화 스텝사이즈 $q_{i}$ 에 대하여 풀기 위하여, 식(3) 내에 식 (1)의 2차 율-양자화 모델 $R_{i}=\frac{a_{i}}{q_{i}}+\frac{b_{i}}{q_{i}^{2}}$ 와 선형 왜곡-양자화 모델 $D_{i}=\alpha_{i} q_{i}$ ( $\alpha_{i}$ 는 모델 파라미터로 서 영상에 따라 적응적으로 결정됨)를 다음 식 (4)와 같이 도입하였다.

$$
\begin{aligned}
& \min \alpha_{1} q_{1}+\alpha_{2} q_{2} \\
& \text { s.t. } \frac{a_{1}}{q_{1}}+\frac{b_{1}}{q_{1}^{2}}+\frac{a_{2}}{q_{2}}+\frac{b_{2}}{q_{2}^{2}} \leq R_{T}
\end{aligned}
$$

즉, 위 식 (4)의 최적화 문제를 정의함으로써 두 부호화기 에서 산출되는 비트스트림의 비트율 합이 정해진 비트율보 다 작거나 같은 조건 하에서 두 복원 영상의 화질 왜곡 합이 최소가 되게 하는 양자화계수를 계산하도록 설계되었다. 또한 서론에서 설명한 바와 같이 좌/우 영상 간의 화질 차이 변화량으로 인한 부작용을 최소화 하기 위하여 화질 차이 $D_{1}-D_{2}=\alpha_{1} q_{1}-\alpha_{2} q_{2}$ 를 $k$ 로 하는 조건을 식 (4)에 추가 하여 최종적으로 다음과 같은 최적화 문제 (5)를 도입하였 다.

$$
\begin{aligned}
& \min \alpha_{1} q_{1}+\alpha_{2} q_{2} \\
& \text { s.t. } \frac{a_{1}}{q_{1}}+\frac{b_{1}}{q_{1}^{2}}+\frac{a_{2}}{q_{2}}+\frac{b_{2}}{q_{2}^{2}} \leq R_{T}
\end{aligned}
$$

위 최적화 문제의 최적해는 첫번째 제약식을 등식으로 바꾼 후 두번째 제약식을 첫번째 제약식에 대입하여 방정 식을 풂으로써 이차 율-양자화 모델 (1)의 해를 구하는 방법 과 동일하게 구할 수 있다. 본 연구에서는 식 (5)에서 구한 최적 양자화 스텝사이즈를 이용하여 최적 양자화계수를 구
하고 이들을 프레임 단위 부호화 과정에 대입함으로써 비 트율 제어를 실시하여, 비트율 제한 조건과 양안 화질 차 일정 유지 조건 하에서 복호된 영상의 화질을 최적화 하도 록 하였다. 참고로 위 최적화 문제의 모델 파라미터 (5)는 영상의 복잡도를 반영하기 위하여 예측 오차인 $\mathrm{MAD}$ 를 포 함하고 있다 ${ }^{[3,4]}$. 여기서 한가지 주의할 점은 본 연구에서는 최적화 문제 (5) 내에 MSE를 이용하여 주관적 화질을 대표 하였지만, 향후에는 주관적 화질을 보다 정확하게 대표할 수 있는 왜곡 척도 기반의 비트율 제어 연구로 확장이 가능 하다는 사실이다.

\section{3. 제안 스테레오스코픽 3D 비디오 합동 비트율 제어 알고리듬}

본 연구에서 제안하는 이종 부호화기 기반 스테레오스코 픽 지상파 방송을 위한 합동 비트율 제어 알고리듬은 GOP 및 프레임 목표 비트율 결정, 최적 양자화계수 계산, 부호화 기 정보 교환, 그리고 파라미터 업데이트 등으로 구성된다. 그림 3은 이러한 합동 비트율 제어 알고리듬의 구조를 보여 준다. 각 $\mathrm{GOP}$ 에 대한 목표 비트율은 이전 $\mathrm{GOP}$ 의 부호화를 완료하고 난 후 남거나 부족한 비트량을 감안하여 결정하 게 된다. $\mathrm{GOP}$ 의 시작 프레임인 I 프레임의 경우 미리 정해 진 고정된 양자화계수를 사용한다.

$\mathrm{P}$ 프레임에 대한 프레임 목표 비트율은 참고문헌 ${ }^{[4]}$ 의 방 법과 비슷한 방식으로 구하게 된다. 즉, I 프레임에 대한 목 표 비트율을 제외한 GOP 목표 비트율을 GOP 내 P 프레임 수로 나누어 고정 프레임 목표 비트율을 결정하며, 부호화 를 진행하면서 GOP 내의 남은 비트량을 고려하여 가변 프 레임 목표 비트율을 결정하고, 이들 고정 프레임 목표 비트 율과 가변 프레임 목표 비트율을 평균한 값으로 프레임 목 표 비트율을 결정한다. 이렇게 해서 구한 프레임 목표 비트 율은 최적화 식 (5)의 목표 비트율 $R_{T}$ 에 대입되고, 앞에서 설명한대로 식 (5)의 최적해는 첫번째 제약식을 부등식에 서 등식으로 바꾸고 두번째 제약식을 첫번째 제약식에 대 입해 방정식을 풂으로써 구하게 된다.

이렇게 합동 비트율 제어기에서 계산된 최적의 양자화계 수는 이종 부호화기에 전달되고 이 양자화계수를 기반으로 


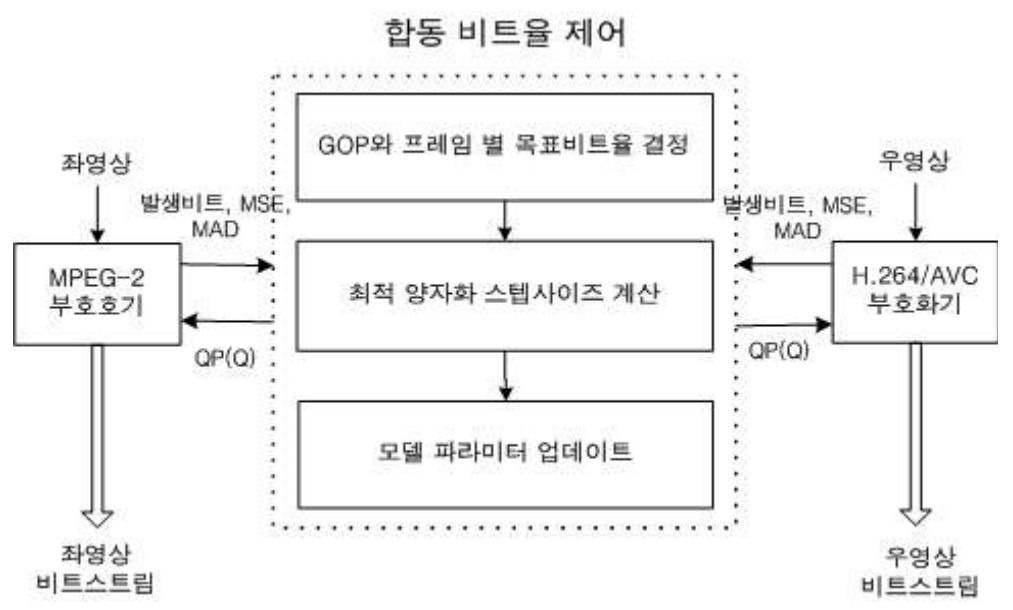

그림 3. 제안 합동 비트율 제어 알고리듬 구조도

Fig. 3. Proposed joint bit rate control algorithm

부호화를 수행한다. 그 결과 양 부호화기로부터 산출된 비 트율은 GOP 목표 비트율 또는 프레임 목표 비트율을 업데 이트 하기 위하여 부호화기로부터 합동 비트율 제어기로 전달된다. 또한 모델 파라미터를 업데이트 하기 위하여 두 부호화기의 화질 왜곡(MSE), 예측 오차(MAD) 값들도 합 동 비트율 제어기에 전달된다. 최적화 식 (5)의 모델 파라미 터 $a_{i}, b_{i}, \alpha_{i}(i=1,2)$ 는 슬라이딩 윈도우를 이용한 선형 회귀 분석 방법 기반 최소제곱합 알고리듬 ${ }^{[3]}$ 을 통하여 계산되고 다음 프레임의 최적 양자화계수 계산에 사용하게 된다.

\section{III. 실험결과}

본 연구에서는 객관적 화질 지표인 MSE 또는 PSNR (Peak Signal to Noise Ratio)이 주관적 화질을 대표할 수 있다는 전제 하에, 다양한 영상에 대하여 두 부호화기 (MPEG-2, H.264/AVC)에서의 압축 성능을 비교 하였다. 좌/우 영상의 경우 유사한 화질을 가진다는 전제하에 스테 레오스코픽 영상 뿐만 아니라 $2 \mathrm{D}$ 의 동일한 영상에 대한 실 험도 실시하였다. 실험에서 사용된 부호화 조건은 표 1 과 같다.

본 실험에서는 우선 기존 알고리듬의 성능을 알아보기 위하여 표 1의 실험 조건 하에서 MPEG-2와 H.264/AVC
에 구현되어있는 비트율 제어 알고리듬을 독립적으로 이 용하여 비트율 제어를 실행하였다. 표 1 에 주어진 각 영상 의 목표 비트율은 MPEG-2와 H.264/AVC에 2:1의 비율로 할당되었다. 그 결과 두 부호화기에서 산출된 영상 화질 의 차이에 있어서, 한 영상 내에서 뿐만 아니라 영상의 종류에 따라서도 큰 차이가 있음을 그림 2 와 표 2 로부터 알 수 있었다.

표 1. 실험조건

Table 1. Experimental condition

\begin{tabular}{|c|c|c|}
\hline & MPEG-2 (좌영상) & H.264/AVC (우영상) \\
\hline 참조 소프트웨어 & TM5 & JM16.0 \\
\hline 프로파일 & Main & Baseline \\
\hline 레벨 & 4 & 40 \\
\hline GOP 구조 & \multicolumn{2}{|c|}{ IPPP } \\
\hline 프레임 수 & \multicolumn{2}{|c|}{50} \\
\hline GOP 크기 & \multicolumn{2}{|c|}{50} \\
\hline 화질차 수준 k & \multicolumn{2}{|c|}{0} \\
\hline 그외 파라미터 & \multicolumn{2}{|c|}{ 디폴트값 } \\
\hline \multirow{3}{*}{$\begin{array}{l}\text { 시험영상 및 } \\
\text { 할당 비트율 }\end{array}$} & 2D CIF (352x288) & $\begin{array}{c}\text { Foreman }(750 \mathrm{Kbps}) \\
\text { Mother\&Daughter }(750 \\
\text { Kbps) }\end{array}$ \\
\hline & $\begin{array}{l}\text { Stereoscopic } \\
480 \times 270\end{array}$ & $\begin{array}{c}\text { Car }(750 \mathrm{Kbps}) \\
\text { Horse }(1.5 \mathrm{Mbps})\end{array}$ \\
\hline & 2D 720p (1280x720) & Night (6 Mbps) \\
\hline
\end{tabular}


제안한 $3 \mathrm{DTV}$ 합동 비트율 제어 방법을 적용하였을 때 두 부호화기로부터 산출되는 P 프레임들의 화질(PSNR)과 산출 비트율을 각각 그림 4과 그림 5에 프레임 별로 표시하 였다. 특히 그림 4의 (a), (b)를 그림 2의 (a), (b)와 비교해보 면 그림 3의 경우 좌/우 영상 화질은 거의 유사하게 함께 움직이고 있음을 알 수 있다. 그림 4의 (c) (e)에서도 제안 합동 비트율 제어 방법을 적용했을 경우 좌/우 영상의 화질 차가 크게 감소되는 결과를 나타냈다. 표 2는 기존 비트율 제어 알고리듬과 제안한 합동 비트율 제어 알고리듬을 각 각 이용한 경우, 두 부호화기에서 산출된 평균 PSNR 및 좌/ 우 영상 화질 절대차의 평균과 화질차의 분산의 결과를 비 교, 정리한 것이다. 표 2에서 사용된 측정방법의 계산은 다 음 식 (6) (9)과 같다.

$$
\begin{gathered}
\overline{P S N R}=\frac{1}{N} \sum_{n=1}^{N}\left\{\left(P S N R_{1}(n)+P S N R_{2}(n)\right) / 2\right\} \\
\overline{\triangle P S N R}=\frac{1}{N} \sum_{n=1}^{N}\left|P S N R_{1}(n)-P S N R_{2}(n)\right| \\
\operatorname{Var}(\overline{\triangle P S N R)} \\
\left.=\frac{1}{N} \sum_{n=1}^{N}\left\{P S N R_{1}(n)-P S N R_{2}(n)-\overline{\triangle P S N R}\right)\right\}^{2} \\
\triangle(\%)=100 \times \frac{\text { 제안방법 }- \text { 기존방법 }}{\text { 기존방법 }}
\end{gathered}
$$

여기서 $P S N R_{i}(n)$ 는 $i(i=1,2)$ 번째 부호화기를 통해 $n$ 번째 프레임이 부호화 되었을 때의 산출 PSNR 값이며, $N$ 은 총 프레임 수이다. 식 (6)은 좌/우 영상의 복호 영상 화 질의 합으로서 제안하는 합동 비트율 최적화 모델 (5)의 목적함수 성능을 대표한다. 표2의 결과로부터 제안 합동 비트율 제어 방법을 통한 비트율 제어의 경우 약 $0.1 \sim 3.4 \%$ 의 화질 향상 효과를 보임을 알 수 있다. 또한 최적화 모델 (5)의 두번째 제약식인 화질차 일정 성능은 식 (7)로부터 측정할 수 있는데, 그 이유는 표1의 실험조건에서 양안 영 상의 화질차 0 을 유지하는 것이 바람직하다고 가정하였으 므로 두 화질의 차가 작을수록 식 (7)도 작은 값을 갖게 되기 때문이다. 표 2로부터 제안한 합동 비트율 제어 방법
이 독립적인 비트율 제어 방법에 비하여 좌/우 영상의 화 질 절대차 평균 $\overline{\triangle P S N R}$ 을 약 59 87\% 감소시켰음을 알 수 있다. 또한 좌/우 영상의 화질차가 시간에 따라 변동량 이 크다면 이러한 현상 또한 시각적 피로를 유발할 수도 있다는 가정 하에 식 (8)를 이용하여 화질차의 분산을 구 하여 보았다. 그 결과 제안 합동 비트율 제어기가 기존의 제어기보다 양안 영상 화질차의 시간에 따른 변화량을 약 $50 \sim 91 \%$ 감소시키는 성능을 보였다. 참고로 그림 5에 표시 된 좌/우 영상의 산출 비트율의 합으로부터 전체 이종 부 호화기 기반 스테레오스코픽 영상의 산출 비트율이 계산 되었고, 이 스테레오스코픽 영상의 산출 비트율은 주어진 목표 비트율에 대하여 약 $-1.85 \sim 0.83 \%$ 오차 수준을 보임 으로써 제안 합동 비트율 제어 방법 역시 기존 독립적인 비트율 제어 방법과 비슷한 수준의 정확도로 목표 비트율

\begin{tabular}{|c|c|c|c|c|}
\hline 측정방법 & 시험영상 & $\begin{array}{c}\text { 독립적 } \\
\text { 비트율 제어 }\end{array}$ & $\begin{array}{c}\text { 제안 합동 } \\
\text { 비트율 제어 }\end{array}$ & $\Delta(\%)$ \\
\hline \multirow{5}{*}{$\overline{P S N R}$} & Foreman & 33.44 & 34.59 & 3.4 \\
\hline & Mother\&Daughter & 40.79 & 41.88 & 2.7 \\
\hline & Car & 35.87 & 36.61 & 2.1 \\
\hline & Horse & 33.44 & 33.49 & 0.1 \\
\hline & Night & 32.85 & 33.45 & 1.8 \\
\hline \multirow{5}{*}{$\overline{\triangle P S N R}$} & Foreman & 2.08 & 0.33 & -84.1 \\
\hline & Mother\&Daughter & 1.20 & 0.49 & -59.2 \\
\hline & Car & 0.75 & 0.21 & -72.0 \\
\hline & Horse & 2.64 & 0.38 & -85.6 \\
\hline & Night & 2.09 & 0.27 & -87.1 \\
\hline \multirow{5}{*}{$\operatorname{Var}(\overline{\triangle P S N R})$} & Foreman & 0.18 & 0.09 & -50.0 \\
\hline & Mother\&Daughter & 1.80 & 0.34 & -81.1 \\
\hline & Car & 0.48 & 0.04 & -91.7 \\
\hline & Horse & 0.58 & 0.15 & -74.1 \\
\hline & Night & 0.20 & 0.05 & -75.0 \\
\hline
\end{tabular}
에 도달함을 알 수 있다.

표 2. 스테레오스코픽 영상 화질 평균, 회질차 평균 및 표준편차, 상대적 향상도 Table 2. Average video quality, average quality difference, standard deviation of quality difference, and relative improvement 
PSNR

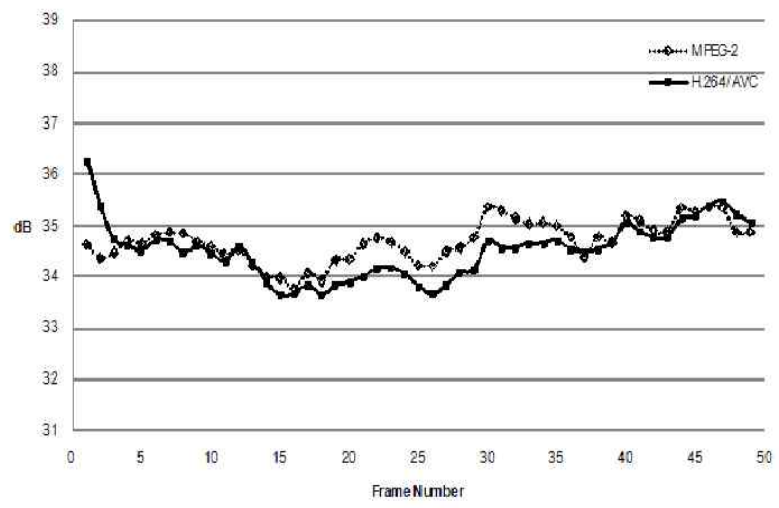

(a) Foreman CIF sequence

PSNR

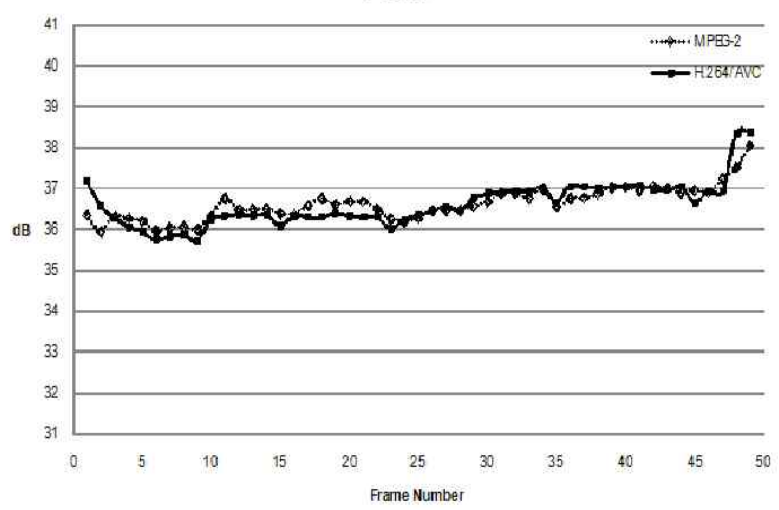

(c) Car 480x270 sequence

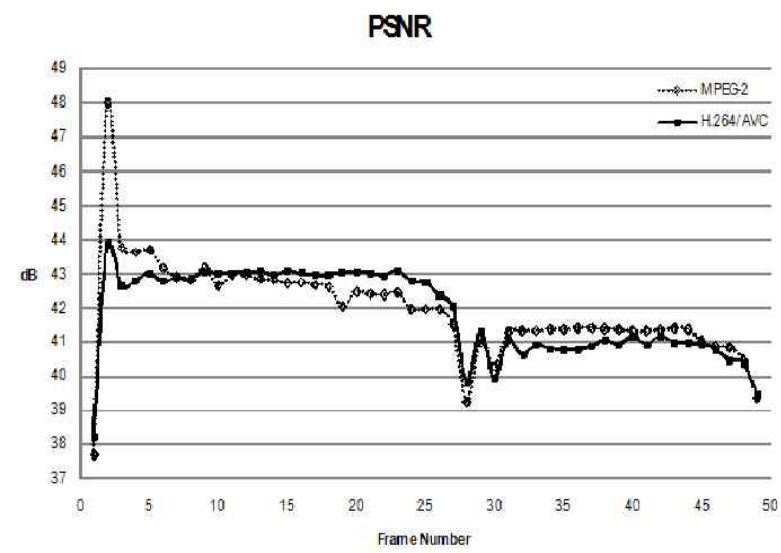

(b) Mother \& Daughter CIF sequence

PSNR

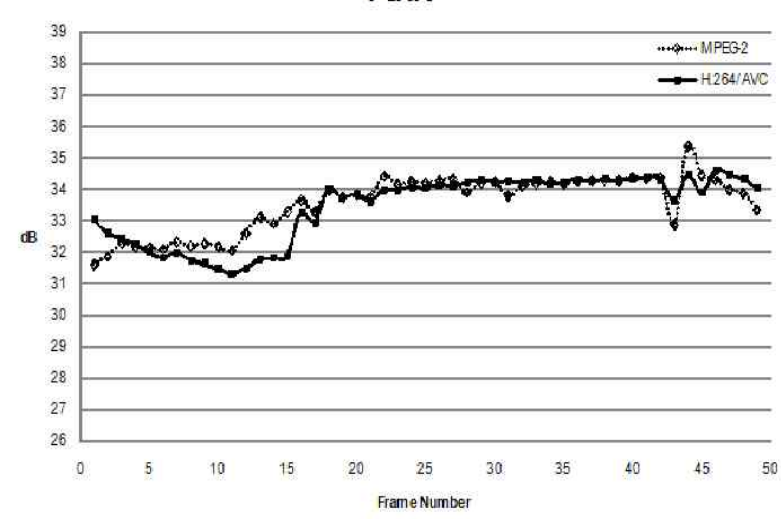

(d) Horse 480x270 sequence

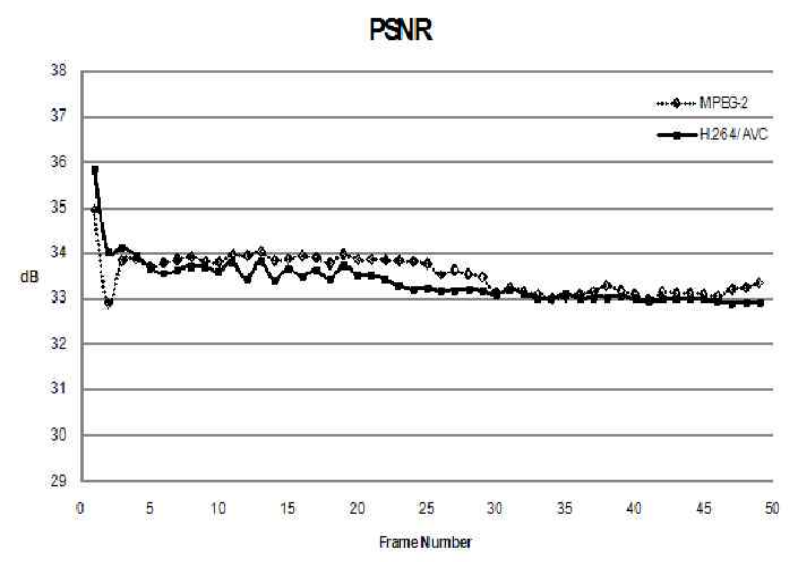

(e) Night 720p sequence

그림 4. 제안 비트율 제어 방법 적용 좌우 영상 화질차

Fig. 4. Quality difference with the proposed joint bit rate scheme 


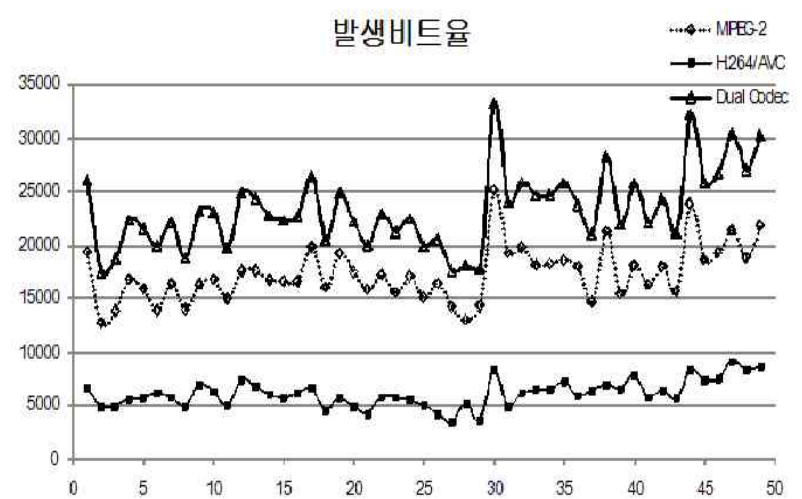

(a) Foreman CIF sequence (Relative error: $0.13 \%$ )

\section{발생비트율}

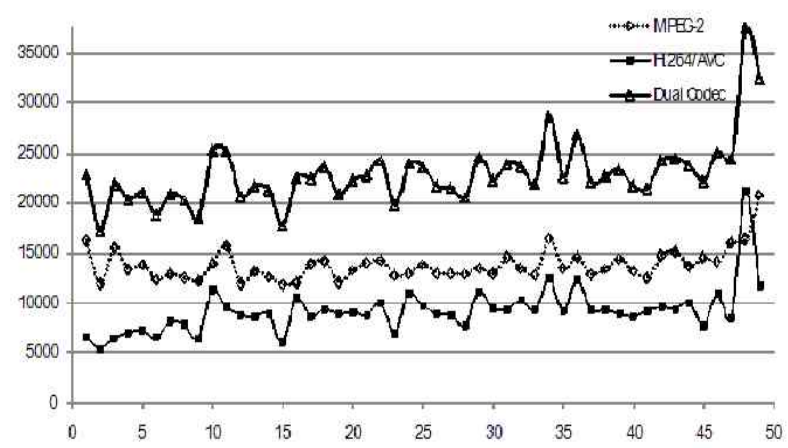

(c) Car 480x270 sequence (Relative error: $-1.85 \%$ )
발생비트율

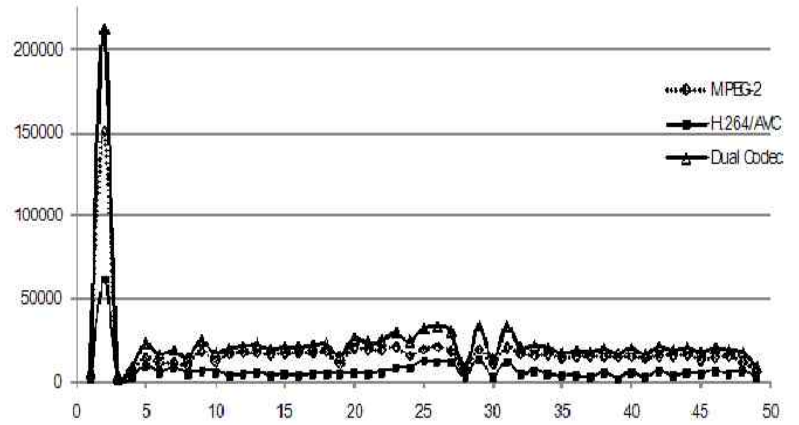

(b) Mother \& Daughter CIF sequence (Relative error: 0.63\%)

\section{발생비트율}

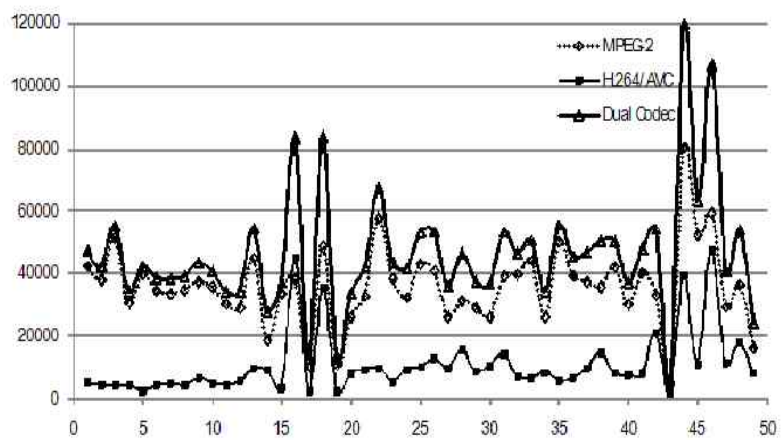

(d) Horse 480x270 sequence (Relative error: $0.83 \%$ )

발생비트율

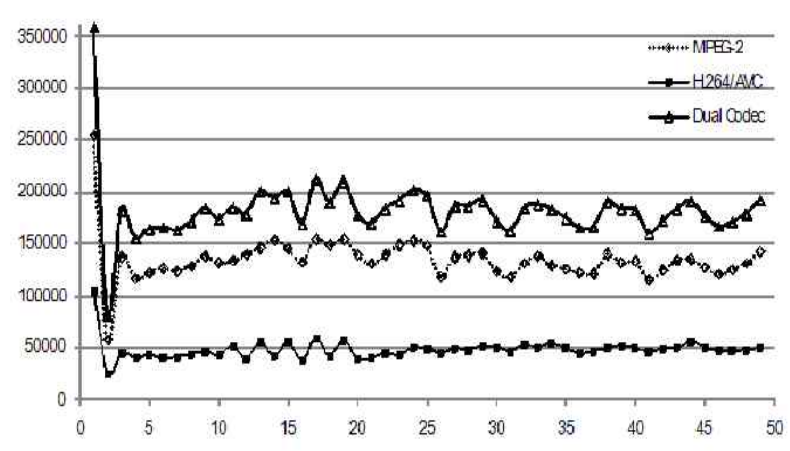

(e) Night 720p sequence (Relative error: -0.33\%)

그림 5. 제안 비트율 제어 방법 적용 좌우 영상 발생 비트율 및 목표 비트율과의 오차

Fig. 5. Generated encoding bit rates with the proposed joint bit rate scheme and relative errors from target bit rates 


\section{IV. 결 론}

본 연구에서는 지상파 스테레오스코픽 3DTV 방송을 위 하여 현재 방송 규격(ATSC 등)에 부합하는 비디오 비트율 제어 방법을 연구하였다. 구체적으로 좌/우 영상의 비트율 합을 목표 비트율에 맞추는 조건 하에서 복호화 된 두 영상 의 화질 합을 최대화하는 합동 비트율 제어 방법을 최적화 관점에서 접근 하였다. 또한 제안한 최적화 문제 내에 좌/우 영상의 화질차를 일정하게 유지하는 제약식을 추가함으로 써 양안 영상의 과도한 화질 차이로 유발될 수 있는 시각적 피로 등을 방지하는 방법을 제안하였다. 실험결과에 따르 면 제안 합동 비트율 제어 방법은 허용할 수준의 오차 범위 내에서 목표 비트율을 맞추는 동시에, 기존 독립적인 비트 율 제어 방법에 비하여 평균적으로 좌/우 영상의 복호 화질 을 약 $2.02 \%$ 향상시켰고, 화질 절대차의 평균은 약 $77.6 \%$, 화질차의 분산은 약 $74.38 \%$ 감소시키는 성능을 보였다.

\section{참 고 문 헌}

[1] M. S. Richer, G. Reitmeier, T. Gurley, G. A. Jones, J. Whitaker, and R. Rast, "The ATSC digital television system," Proceedings of the IEEE, Special Issue on Global Digital Television: Technology and Emerging Services, pp.37 - 43, Jan. 2006.

[2] 최병호, 김용환, 김제우, 박지호, “스테레오 $3 \mathrm{D}$ 방송을 위한 비디오 부호 화 기술”, 방송공학회지, 15 권 1 호, pp.24-36, 2010.

[3] H.-J. Lee, T. Chiang, and Y.-Q. Zhang, "Scalable rate control for MPEG-4 video," IEEE Trans. Circuits Syst. Video Technol., vol. 10, pp. 878 - 894, Sept. 2000.

[4] Z. G. Li, F. Pan, K. P. Lim, G. Feng, X. Lin and S. Rahardja, "Adaptive basic unit layer rate control for JVT," JVT-G012-r1, 7th Meeting, Pattaya II, Thailand, Mar. 2003.

[5] Lew B. Stelmach and W. James Tam, "Stereoscopic image coding: Effect of disparate image-quality in left- and right-eye views," Signal Processing: Image Communication, Vol. 14, pp. 111-117, 1998.

[6] P. Seuntiens, L. Meesters, and W. IJsselsteijn, "Perceived quality of compressed stereoscopic images: effects of symmetric and asymmetric JPEG coding and camera separation," ACM Transactions on Applied Perception, vol. 3, no. 2, pp. 95 - 109, Apr. 2006.

[7] T. Wiegand et al., "Overview of H.264/AVC Video Coding Standard", IEEE Trans. Circuits Syst. Video Technol., Vol. 13, No. 7, pp. 560 576, July 2003.

[8] ISO/IEC JTC1/SC29/WG11, Test model 5, 1993.

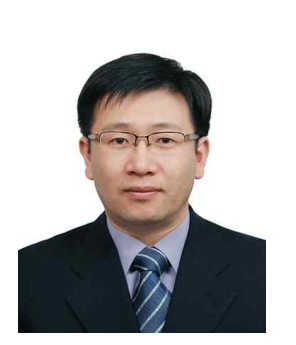

\section{장 용 준}

- 1997년 8월 : 서울대학교 산업공학과 공학사

- 1997년 7월 1998년 10월 : SK텔레콤

- 1999년 9월 2000년 8월 : University of Wisconsin-Madision, Industrial Engineering, 석사

- 2005년 6월 현재 : 한국과학기술원 정보통신공학과 박사과정

- 주관심분야 : 비디오 통신, 디지털 방송, 비디오 코딩

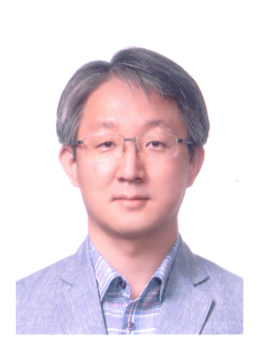

\section{김 문 철}

- 1989년 2월 : 경북대학교 전자공학과 공학사

- 1992년 12월 : University of Florida, Electrical and Computer Engineering, 석사

- 1996년 8월 : University of Florida, Electrical and Computer Engineering, 박사

- 1997년 1월 2001년 2월 : 한국전자통신연구원, 선임연구원

- 2001년 2월 2005년 8월 : 한국정보통신대학교 공학부 조교수

- 2005년 9월 2009년 2월 : 한국정보통신대학교 공학부 부교수

- 2009년 3월 현재 : 한국과학기술원 전기및전자공학과 부교수

- 주관심분야 : 비디오코딩, 패턴인식, 비주얼 정보처리, UHDTV, IPTV, UXTV, 멀티미디어 시스템 